\title{
Effects of young persimmon fruit powder on rice cookie quality
}

\author{
Jong-Hwan Seong*, Han-Sol Park, Hun-Sik Chung, Dong-Seob Kim, Han-Soo Kim, \\ Young-Guen Lee \\ Department of Food Science and Technology, Pusan National University, Miryang 50463, Korea
}

\section{어린 감 과실 분말 첨가가 쌀쿠키의 품질특성에 미치는 영향}

\author{
성종환* · 박한솔·정헌식 · 김동섭·김한수 · 이영근 \\ 부산대학교 식품공학과
}

\begin{abstract}
This study was conducted to develop rice cookies added with young persimmon fruits. Effects of varying amounts (0-12\%) of the fruit powder from a young astringent persimmon fruit (picked at July) on the quality characteristics of rice cookies were studied. Ingredients [rice (Oryza sativa subsp. japonica 'Ilpum') flours, persimmon (Diospyros kaki Thunb. 'Cheongdobansi') powder, sugar, butter, salt, baking powder, egg] were mixed, cut (thickness 3 mm, diameter $35 \mathrm{~mm}$ ), baked at $170-180^{\circ} \mathrm{C}$ for $9 \mathrm{~min}$, cooled, and packaged in polyethylene/nylon bags. The loss rate and spread factor after baking of cookies increased and then decreased with an increase in the amount of fruit powder added. The moisture content and color values $\left(\mathrm{L}^{*}\right.$ and $\left.\mathrm{a}^{*}\right)$ of cookies decreased with an increase in the amount of the persimmon powder added. Phenolic compounds content and DPPH radicals scavenging activity increased with an increase in persimmon powder content; in particular, the DPPH activity of the cookies sharply increased after the addition of $3 \%$ persimmon powder. These results suggest that the addition of the young persimmon fruit powder affected the quality characteristics of rice cookies and this fruit powder (approximately $3 \%$ ) can be utilized as an additive during rice cookie processing.
\end{abstract}

Key words : persimmons, rice, cookies, antioxidant activity, baking

\section{서 론}

감나무(Diospyros kaki Thunb.)는 동아시아 지역이 원산 지와 주재배지이며, 원예학적인 품종은 다양하지만 성숙한 과실의 삽미 존재유무에 따라 떫은감과 단감 나무로 양분된 다. 감나무 산물인 과실, 잎, 꼭지 등은 예로부터 식용 이외 에도 한방 및 민간요법에서 숙취해소와 기침 및 딸꾹질 치료에 유효한 것으로 알려져 있다(1). 최근에는 이러한 감나무 산물이 항산화작용, 항돌연변이작용, 항알레르기작 용, 항암작용, 항고혈압작용 및 혈액응고저해작용 등과 같

*Corresponding author. E-mail : sjh5353@pusan.ac.kr Phone : 82-55-350-5353, Fax : 82-55-350-5359

Received 13 October 2017; Revised 4 December 2017; Accepted 16 December 2017.

Copyright (c) The Korean Society of Food Preservation. All rights reserved.
은 건강 기능성(2-7)을 가지는 것으로 밝혀지고 있다. 더불 어 감나무 유래 자원의 고부가가치 창출과 활용성 증대를 위한 연구도 활발히 수행되어, 성장 중 감 과실 및 잎의 화학성분 변화 $(8,9)$, 품종별 감 과피와 꽃의 화학성분 비교 $(10,11)$, 과실을 활용한 식초, 와인, 조청, 빵, 설기떡 등의 제조(12-16), 잎을 활용한 차, 냉면, 쿠키의 제조(17-19), 꽃 을 활용한 차 제조(20) 및 과피를 활용한 색소, 식초의 제조 $(21,22)$ 등이 보고된바 있다. 그러나 아직 미이용 감나무 유래 자원의 유효이용에 관한 연구는 미흡하며 기존 활용자 원 이외의 성숙도와 부위에 대한 연구가 필요한 실정이다. 이의 일환으로 녹색 어린 감 과실은 성숙과보다 페놀성 물질 함량과 항산화능이 높은 장점이 있어 식품분야에서 활용 연구가 기대되지만(8), 아직 두부 제조에 첨가한 경우 (23)를 제외하면 미미한 실정이다.

벼는 아시아종(Oryza sativa L.)과 아프리카종(Oryza glaberrima Steud.)으로 양분되며, 아시아종은 다시 japonica 
type, indica type 및 javanica type으로 세분된다. 국내산 쌀의 대부분은 japonica type이며 이는 상대적으로 형태가 둥글 고 짧으며 아밀로펙틴의 함량이 높아 취반 후 찰기를 가진 다. 쌀은 영양 공급원인 주식으로서의 가치뿐만 아니라 혈 중 콜레스테롤 조절, 혈당 조절, 혈압 조절, 기억력 개선 및 위장관기능 개선 등의 건강 기능성도 가지는 것으로 알려져 있다(24). 국내 쌀 수급현황을 보면 자급률이 높은 생산량에 비해 소비량이 감소하는 추세에 있어 수급안정화 와 식량자급률 제고를 위한 노력이 필요하며, 이를 위한 방편으로 쌀의 고품질화와 쌀을 활용한 고부가가치 가공식 품화에 관한 연구수행에 동반하여, 쌀 쿠키에 관한 연구도 일부 수행되어서, 밀가루 대체 기능성 쌀쿠키 제조(25), 쌀 의 아밀로스 함량에 따른 쿠키의 품질특성(26), 음나무, 스 테비아, 곰치 분말을 첨가한 쌀쿠키 제조(27-29), 쌀가루에 유화제를 첨가한 쿠키 제조(30) 및 호화 쌀가루 이용 쌀쿠키 제조(31)에 관한 보고가 있지만 밀가루나 글루텐 무첨가 쌀가루 쿠키 제조에 어린 감 과실을 활용한 연구는 거의 찾아보기 힘든 실정이다.

따라서 본 연구에서는 녹색 어린 감 과실의 제과분야에 서의 활용성 증대와 쌀쿠키의 고부가가치화를 위한 기본 자료를 얻기 위하여, 어린 감 과실 분말 첨가량에 따른 쌀 쿠키의 이화학적 품질 특성 및 항산화성을 각각 조사하였 다.

\section{재료 및 방법}

\section{재 료}

실험용 감 분말은 2016년 7월 중순 경상북도 청도군에서 반시 품종의 과수로부터 어린 과실을 채취하여 세척, 꼭지 제거한 후 슬라이스 처리하였다. 이를 cabinet-type 열풍건 조기(JSOF-150, JSR Co., Gongju, Korea)를 이용하여 $50^{\circ} \mathrm{C}$ 에서 건조한 후 분쇄기(JL-1000, Hibell Co., Hwaseong, Korea)로 분쇄하고, 체질(40 mesh)한 다음 냉동 보관하면서 사용하였다. 이때 감의 채취 시기는 성숙 중 페놀물질의 함량변화를 조사한 전보(8)를 참고하여 결정하였다. 쿠키 용 미분은 2016년 경상북도 상주산 멥쌀 '일품' 품종 $(O$. sativa subsp. japonica cv. Ilpum)으로 건식 분쇄한 것을 산지 미곡상에서 구매하여 체질(40 mesh)하여 사용하였다. 설탕 (CJ Cheiljedang Co., Incheon, Korea), 무염버터(Seoul milk Co., Yongin, Korea), 식염(Hanju Co., Ulsan, Korea), 베이킹 파우더(Jeonwon Food, Gimpo, Korea) 및 계란(Haemil Farming Association Co., Yeoju, Korea)은 마트에서 구입하 여 사용하였다.

\section{쿠키 제조}

쌀쿠키의 원료 배합비는 예비실험을 통하여 결정하였으
며, 쌀가루는 $200 \mathrm{~g}, 197 \mathrm{~g}, 194 \mathrm{~g}, 188 \mathrm{~g}, 176 \mathrm{~g}$ 으로, 녹색 어린 감 분말은 쌀가루에 대응하여 대체하는 양을 기준으로 $0 \mathrm{~g}(0 \%), 3 \mathrm{~g}(1.5 \%), 6 \mathrm{~g}(3 \%), 12 \mathrm{~g}(6 \%), 24 \mathrm{~g}(12 \%)$ 으로 각각 설정하였으며, 여기에 설탕은 $40 \mathrm{~g}$, 버터는 $50 \mathrm{~g}$, 식염은 $0.8 \mathrm{~g}$, 베이킹파우더는 $1 \mathrm{~g}$, 계란은 $40 \mathrm{~g}$ 으로 고정하였다. 쿠키의 제조과정은, 버터를 휘핑한 후 설탕과 식염을 넣고 설탕이 녹을 때 까지 크림화하고 계란을 나누어 넣고 혼합 한 다음 여기에 베이킹파우더, 감과 쌀가루를 넣고 혼합하 고 $10^{\circ} \mathrm{C}$ 냉장고에서 30 분간 숙성시키고 rolling pin을 이용 하여 두께가 $3 \mathrm{~mm}$ 가 되도록 넓게 핀 후 직경 $35 \mathrm{~mm}$ 원형 틀로 찍어 반죽을 성형하였다. 성형품을 팬에 얹어 윗불 $180^{\circ} \mathrm{C}$, 아랫불 $170^{\circ} \mathrm{C}$ 로 예열된 전기오븐(FDO-7102, Daeyung Bakery Machinery Ind., Co., Ltd., Seoul, Korea)에 넣고 9분간 구운 후 실온에서 1시간 냉각하고 플라스틱 봉지로 밀봉 포장하여 분석용 시료로 사용하였다.

\section{손실률 측정}

손실률(loss rate)은 굽기 전후의 무게 $(\mathrm{g})$ 를 측정하여 다음 식으로 계산하였다.

$$
\text { 손실률 }(\%)=\frac{\text { 굽기 전 무게 }(\mathrm{g}) \text {-구운 후 무게 }(\mathrm{g})}{\text { 굽기 전 무게 }(\mathrm{g})} \times 100
$$

\section{퍼짐성 지수 측정}

퍼짐성 지수(spread factor)는 쿠키의 직경과 두께를 측정 하여 다음 식으로 계산하였다(32). 이때 직경은 쿠키 6개를 나란히 수평으로 정렬하여 전체 길이를 측정한 후 쿠키 1 개에 대한 평균값을 구하였으며, 두께는 쿠키 6개를 수직 으로 쌓은 후 전체 높이를 측정한 후 쿠키 1 개에 대한 평균 값을 구하였다.

$$
\text { 퍼짐성지수 }=\frac{\text { 쿠키 } 6 \text { 개의 평균직경 }(\mathrm{mm})}{\text { 쿠키 } 6 \text { 개의 평균두께 }(\mathrm{mm})} \times 100
$$

\section{겉보기 밀도 측정}

쿠키의 겉보기 밀도(bulk density)는 종자치환법(31)으로 부피 $\left(\mathrm{m}^{3}\right)$ 를 구하고 무게 $(\mathrm{kg})$ 와의 비로 계산하였다.

\section{수분 함량 및 수분활성도 측정}

쿠키의 수분 함량은 $105^{\circ} \mathrm{C}$ 상압가열건조법으로 측정하 였고, 수분활성도는 수분활성도 측정기(Hygromer A2, Rotronic instrument Co., Huntington, NY, USA)를 이용하여 측정하였다.

색도 측정

색도는 백색판 $\left(\mathrm{L}^{*}=97.79, \mathrm{a}^{*}=-0.38, \mathrm{~b}^{*}=2.05\right)$ 으로 보정한 colorimeter(CR-400, Konika Minolta Inc., Tokyo, Japan)를 
사용하여 쿠키 윗면의 $\mathrm{CIE} \mathrm{L}^{*}, \mathrm{a}^{*}, \mathrm{~b}^{*}, \mathrm{~h}^{\circ}, \mathrm{C}^{\star}$ 값을 각각 측정하 였다. $\mathrm{L}^{*}$ 값은 lightness를, $+\mathrm{a}^{*}$ 와 $-\mathrm{a}^{*}$ 값은 redness와 greenness 를, $+\mathrm{b}^{\star}$ 와 $-\mathrm{b}^{\star}$ 값은 yellowness와 blueness를 각각 나타낸다. $\mathrm{h}^{\circ}$ 값은 색상(red-purple: $0^{\circ}$, yellow: $90^{\circ}$, bluish-green: $180^{\circ}$, blue: $\left.270^{\circ}\right)$ 을 나타내고, $a>0, b>0$ 이면 $h^{\circ}=\tan ^{-1}(b / a)$ 로, $a<0$, $\mathrm{b}>0$ 이면 $\mathrm{h}^{\circ}=180^{\circ}+\tan ^{-1}(\mathrm{~b} / \mathrm{a})$ 으로 각각 계산된다. $\mathrm{C}^{\star}$ 값은 채 도를 나타내고, $\mathrm{C}^{\star}=\left(\mathrm{a}^{\star 2}+\mathrm{b}^{\star 2}\right)^{1 / 2}$ 로 계산된다.

\section{경도 측정}

경도는 rheometer(Compac-100II, Sun Scientific Co., Tokyo, Japan)의 경도 테스트를 이용하여 쿠키 파괴의 최대 응력을 측정하였다. 이때 측정조건으로 probe의 직경은 3 $\mathrm{mm}$, 진입깊이는 $2 \mathrm{~mm}$, 테이블 속도는 $120 \mathrm{~mm} / \mathrm{min}$ 을 각각 사용하였다.

\section{총페놀 함량 측정}

총페놀 함량은 쿠키 $5 \mathrm{~g}$ 에 $80 \%$ 에탄올 $45 \mathrm{~mL}$ 가하고 24시간 추출, 여과한 후 시료 액을 취해 Folin-Ciocalteu의 방법(33)으로 측정하였다. 즉, 시료 액 $2 \mathrm{~mL}$ 를 시험관에 취하고 여기에 Folin-Ciocalteu reagent $2 \mathrm{~mL}$ 를 가하고 3 분간 정치한 다음 $10 \% \mathrm{Na}_{2} \mathrm{CO}_{3}$ 용액 $2 \mathrm{~mL}$ 를 가하였다. 이 혼합액 을 1시간 동안 정치한 후 spectrophotometer(UV1800, Shimadzu, Kyoto, Japan)를 이용하여 $760 \mathrm{~nm}$ 에서 흡광도를 측정하였고, 정량은 gallic acid 표준품으로 검량선을 작성 하여 실시하였다.

\section{$\mathrm{DPPH}$ 유리기 소거능 측정}

1,1-diphenyl-2-picrylhydrazyl(DPPH) 유리기 소거능은 쿠키 $5 \mathrm{~g}$ 에 $80 \%$ 에탄올 $45 \mathrm{~mL}$ 가하고 24시간 추출, 여과한 후 시료 액을 취해 Blois의 방법(34)으로 측정하였다. 즉, 추출 시료액 $0.2 \mathrm{~mL}$ 에 $0.4 \mathrm{mmol} / \mathrm{L} \mathrm{DPPH}$ 용액 $0.8 \mathrm{~mL}$ 에 에탄올 $2.8 \mathrm{~mL}$ 을 혼합한 것을 가하고 10 초간 강하게 진탕하 고 10분간 정치한 후에 spectrophotometer(UV1800, Shimadzu) 를 이용하여 $525 \mathrm{~nm}$ 에서 흡광도를 측정하였다. DPPH 유리 기 소거능은 다음 식으로 계산하였다.

$$
\mathrm{DPPH} \text { 유리기 소거능 }(\%)=\left(1-\frac{\text { 시료액의 흡광도 }}{\mathrm{DPPH}}\right) \times 100
$$

\section{통계처리}

실험결과는 반복실험의 평균표준편차로 나타내었고, IBM SPSS statistics(23, IBM Corp., Armonk, NY, USA)를 이용하여 분산분석과 Duncan's multiple range test $(\mathrm{p}<0.05)$ 를 실시하였다.

\section{결과 및 고찰}

손실률, 퍼짐성 지수 및 겉보기 밀도 비교

어린 감 과실 분말의 첨가량에 따른 쌀쿠키 베이킹 시 손실률, 퍼짐성 지수 및 겉보기 밀도를 각각 측정한 결과는 Table 1에 나타내었다. 손실률은 베이킹에 따른 무게감소를 나타내는 척도이며 감 분말 첨가 쌀쿠키의 손실률은 감 분말 1.5-6\% 첨가구가 무첨가구보다 유의적으로 높은 수준 을 보였다. 퍼짐성은 베이킹에 따른 반죽의 두께 감소와 직경 증가 정도를 나타내는 척도로 사용되며, 이는 원료 특성, 반죽 조건 및 베이킹 조건 등에 의해 결정되는 것으로 알려져 있다. 감 분말 첨가 쌀쿠키의 퍼짐성 지수는 감 분말 $3 \%$ 첨가까지는 약간씩 증가하는 경향이었으나 $6 \%$ 이상 첨가에서는 감소함을 보였다. 한편, 음나무잎 분말도 $5 \%$ 첨가까지 쌀쿠키의 퍼짐성이 증가되었다는 보고(27)가 있 지만, 밀가루 쿠키의 경우는 감잎 $4 \%$ 첨가까지 퍼짐성 감소 를 초래하였다는 보고(19)가 있다. 이러한 결과는 각종 첨가 물에 의한 반죽의 수분함량과 점성 변화에 따른 결과로 여겨진다(19). 겉보기 밀도는 베이킹에 따른 반죽의 팽창 정도를 나타내며 이 값의 증가는 팽창이 억제됨을 나타내고 쿠키의 조직감과 연관성이 높은 물리적 특성으로 알려져 있다. 감 분말 첨가 쌀쿠키의 겉보기 밀도는 감 분말 $1.5 \%$ 첨가구에서 무첨가구보다 약 2.5 배 증가하였고 그 외는 1.6-1.7배 정도 증가함을 보였다. 이러한 감 분말 첨가량의 증가와 더불어 겉보기 밀도가 증가한 결과는 스테비아잎 첨가 쌀쿠키(28)에서의 경우와 유사하였다. 이로써 쌀쿠키 제조 시 감 분말첨가는 쿠키의 부피 증대를 억제하는 것으 로 확인되었다.

수분함량 및 수분활성도 비교

식품의 수분함량과 수분활성도는 일반적으로 품질과 저

Table 1. Loss rate, spread factor, and bulk density of rice cookies added with different amounts of young persimmon powder

\begin{tabular}{cccccc}
\hline & \multicolumn{5}{c}{ Persimmon powder (\%) } \\
\cline { 2 - 6 } Property & 0 & 1.5 & 3 & 6 & 12 \\
\hline Loss rate (\%) & $9.76 \pm 3.51^{\mathrm{bl})}$ & $20.22 \pm 1.14^{\mathrm{a}}$ & $20.71 \pm 2.41^{\mathrm{a}}$ & $23.34 \pm 2.68^{\mathrm{a}}$ & $6.12 \pm 4.10^{\mathrm{b}}$ \\
Spread factor & $7.03 \pm 0.12^{\mathrm{ab}}$ & $7.29 \pm 0.32^{\mathrm{a}}$ & $7.37 \pm 0.31^{\mathrm{a}}$ & $6.62 \pm 0.07^{\mathrm{b}}$ & $6.65 \pm 0.28^{\mathrm{b}}$ \\
Bulk density $\left(\mathrm{kg} / \mathrm{m}^{3}\right)$ & $741.86 \pm 184.99^{\mathrm{c}}$ & $1,916.92 \pm 301.83^{\mathrm{a}}$ & $1,200.75 \pm 362.20^{\mathrm{bc}}$ & $1,207.91 \pm 204.14^{\mathrm{bc}}$ & $1,301.29 \pm 140.87^{\mathrm{b}}$ \\
\hline
\end{tabular}

${ }^{1)}$ Means \pm SD $(n=3)$ in a row followed by same letter are not significantly different by Duncan's multiple range test $(\mathrm{p}<0.05)$ 
장 안정성의 척도로 사용되며, 어린 감 과실 분말의 첨가량 을 달리한 쌀쿠키의 수분함량과 수분활성도를 측정한 결과 는 Fig. 1 에 나타내었다. 수분함량은 감 분말의 첨가량이 높아질수록 증가하는 경향을 보였다. 수분활성도에서도 감 분말 첨가량의 영향이 수분함량의 경우와 유사함을 보였고 수준은 0.6-0.7 범위를 보였다. 이러한 결과는 감 분말에 함유된 수분에 기인된 것이며 제품이 약해지고 저장 안정성 이 낮질 것으로 여겨지며, 음나무잎 또는 스테비아잎 첨가 쌀쿠키에서도 유사한 결과가 보고 $(27,28)$ 된 바 있다.

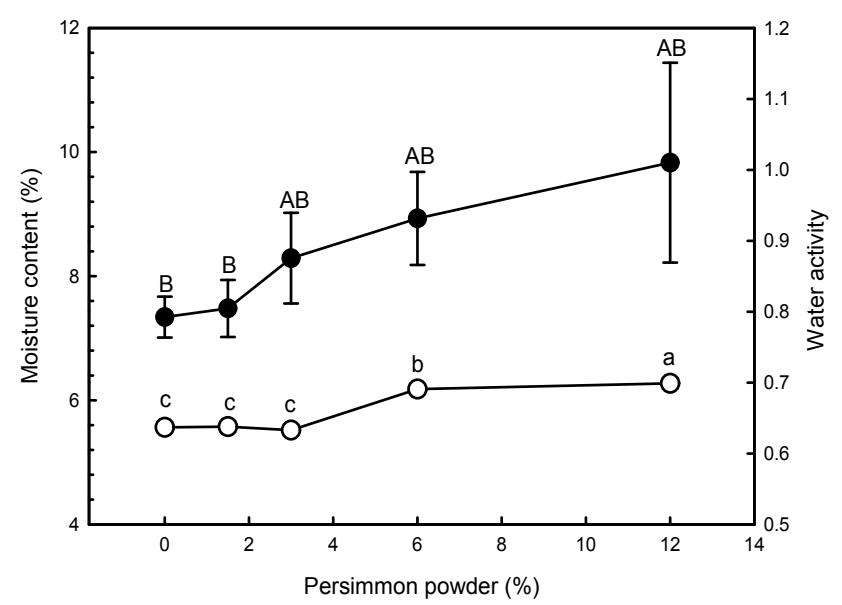

Fig. 1. Moisture content $(\bigcirc)$ and water activity $(\bigcirc)$ of rice cookies added with different amounts of young persimmon powder.

Means \pm SD ( $\mathrm{n}=3$ ) with different letters above a symbol are significantly different by Duncan's multiple range test $(\mathrm{p}<0.05)$.

\section{색도 비교}

어린 감 과실 분말의 첨가량에 따른 쌀쿠키의 굽기 전후 표면색도를 측정 비교한 결과는 Table 2 와 같다. 색도 $\mathrm{L}^{*}$ 값 은 굽기 전후 모두 감 분말의 첨가량이 증가할수록 유의적 인 감소(p<0.05)를 보였으며 굽기에 의해서는 큰 폭으로
증가함을 보였다. 색도 $\mathrm{a}^{*}$ 값은 굽기 전후 모두 감 분말의첨 가량 증가에 따라 음의 값에서 양의 값으로 증가함을 보였 고 굽기에 의해서는 $1.5 \%$ 이하 첨가구에서는 소폭 감소하 였으나 $3 \%$ 이상 첨가구에서는 소폭 증가함을 보였다. 이러 한 감 분말의 첨가량에 따른 $\mathrm{L}^{*}$ 값의 감소와 $\mathrm{a}^{*}$ 값의 증가 패턴은 감 분말 첨가 두부(23)에서의 결과와 유사하였다. 색도 $\mathrm{b}^{\star}$ 값은 굽기 전에는 $3 \%$ 이하 첨가구간에는 유의적인 차이를 보이지 않았으나 $6 \%$ 이상 첨가구에서는 첨가량에 따라 증가함을 보였다. $\mathrm{h}^{\circ}$ 값은 감분말의 첨가량 증가에 따 라 감소함을 보였으며, 굽기에 의해서는 $1.5 \%$ 첨가까지는 증가함을 $3 \%$ 이상 첨가부터는 감소함을 각각 보였다. $\mathrm{C}^{\star}$ 값 은 감분말의 첨가량에 따른 영향이 $\mathrm{b}^{\star}$ 값의 경우와 유사함을 보였다. 이로써 쌀쿠키의 색도는 어린 감 분말의 첨가에 의해 명도는 낮아지고 적색도는 증가하는 것으로 확인되었 다. 이러한 결과의 원인은 감 과실 분말에 포함된 녹색색소 (29)와 효소적 및 비효소적 갈변(35) 때문인 것으로 생각된다.

\section{경도 비교}

어린 감 과실 분말의 첨가량을 달리하여 만든 쌀쿠키의 경도를 측정한 결과는 Fig. 2 와 같다. 경도는 감 분말 첨가량 $3 \%$ 까지는 유의적인 차이를 보이지 않았으나 그 이상의 첨가량에서는 낮아짐을 보였다. 음나무잎과 곰취 분말 첨 가 쌀쿠키에서도 각 분말의 첨가량이 증가할수록 경도가 낮아지며 이는 수분함량과 밀접한 관계가 있는 것으로 알려 져 있으며(27,29), 앞서 언급한 쿠키의 수분함량 결과와 유 사하였다. 이로써 쌀쿠키 제조 시 어린 감 분말을 쌀가루 대비 $3 \%$ 까지 첨가는 경도에 거의 영향을 미치지 않는 것으 로 확인되었다.

총페놀 함량 및 항산화능 비교

어린 감 과실 분말의 첨가량에 따른 쌀쿠키의 총페놀

Table 2. Color of rice cookies added with different amounts of young persimmon powder

\begin{tabular}{ccccccc}
\hline \multirow{2}{*}{ Color value } & Baking & \multicolumn{5}{c}{ Persimmon powder (\%) } \\
\cline { 3 - 7 } & & 0 & 1.5 & 3 & 6 & 12 \\
\hline \multirow{2}{*}{$\mathrm{L}^{*}$} & Before & $72.45 \pm 1.02^{\mathrm{al})}$ & $67.24 \pm 1.46^{\mathrm{b}}$ & $64.94 \pm 0.70^{\mathrm{c}}$ & $62.79 \pm 0.49^{\mathrm{d}}$ & $59.97 \pm 0.89^{\mathrm{e}}$ \\
& After & $82.78 \pm 0.61^{\mathrm{a}}$ & $75.85 \pm 0.63^{\mathrm{b}}$ & $73.77 \pm 0.58^{\mathrm{c}}$ & $71.58 \pm 0.66^{\mathrm{d}}$ & $67.66 \pm 0.73^{\mathrm{e}}$ \\
\hline \multirow{2}{*}{$\mathrm{a}^{*}$} & Before & $-1.46 \pm 0.10^{\mathrm{e}}$ & $-0.10 \pm 0.26^{\mathrm{d}}$ & $0.28 \pm 0.27^{\mathrm{c}}$ & $0.71 \pm 0.20^{\mathrm{b}}$ & $1.31 \pm 0.13^{\mathrm{a}}$ \\
& After & $-2.53 \pm 0.16^{\mathrm{e}}$ & $-0.19 \pm 0.10^{\mathrm{d}}$ & $0.57 \pm 0.28^{\mathrm{c}}$ & $1.24 \pm 0.22^{\mathrm{b}}$ & $2.41 \pm 0.30^{\mathrm{a}}$ \\
\hline \multirow{2}{*}{$\mathrm{b}^{*}$} & Before & $19.50 \pm 0.75^{\mathrm{c}}$ & $18.97 \pm 0.48^{\mathrm{c}}$ & $19.07 \pm 0.58^{\mathrm{c}}$ & $20.57 \pm 0.24^{\mathrm{b}}$ & $21.78 \pm 0.43^{\mathrm{a}}$ \\
& After & $22.77 \pm 0.50^{\mathrm{b}}$ & $20.32 \pm 0.66^{\mathrm{d}}$ & $21.10 \pm 0.71^{\mathrm{c}}$ & $23.07 \pm 0.63^{\mathrm{b}}$ & $26.09 \pm 0.90^{\mathrm{a}}$ \\
\hline \multirow{2}{*}{$\mathrm{h}^{\circ}$} & Before & $94.28 \pm 0.16^{\mathrm{a}}$ & $90.32 \pm 0.78^{\mathrm{b}}$ & $89.16 \pm 0.79^{\mathrm{c}}$ & $88.03 \pm 0.58^{\mathrm{d}}$ & $86.56 \pm 0.35^{\mathrm{e}}$ \\
& After & $96.35 \pm 0.41^{\mathrm{a}}$ & $90.53 \pm 0.29^{\mathrm{b}}$ & $88.46 \pm 0.73^{\mathrm{c}}$ & $86.93 \pm 0.53^{\mathrm{d}}$ & $84.73 \pm 0.58^{\mathrm{e}}$ \\
\hline \multirow{2}{*}{$\mathrm{C}^{*}$} & Before & $19.55 \pm 0.76^{\mathrm{c}}$ & $18.97 \pm 0.48^{\mathrm{c}}$ & $19.08 \pm 0.59^{\mathrm{c}}$ & $20.58 \pm 0.23^{\mathrm{b}}$ & $21.81 \pm 0.43^{\mathrm{a}}$ \\
& After & $22.91 \pm 0.50^{\mathrm{b}}$ & $20.32 \pm 0.66^{\mathrm{d}}$ & $21.11 \pm 0.72^{\mathrm{c}}$ & $23.11 \pm 0.63^{\mathrm{b}}$ & $26.20 \pm 0.91^{\mathrm{a}}$ \\
\hline
\end{tabular}

\footnotetext{
${ }^{1)}$ Means \pm SD $(n=3)$ in a row followed by same letter are not significantly different by Duncan's multiple range test $(\mathrm{p}<0.05)$.
} 


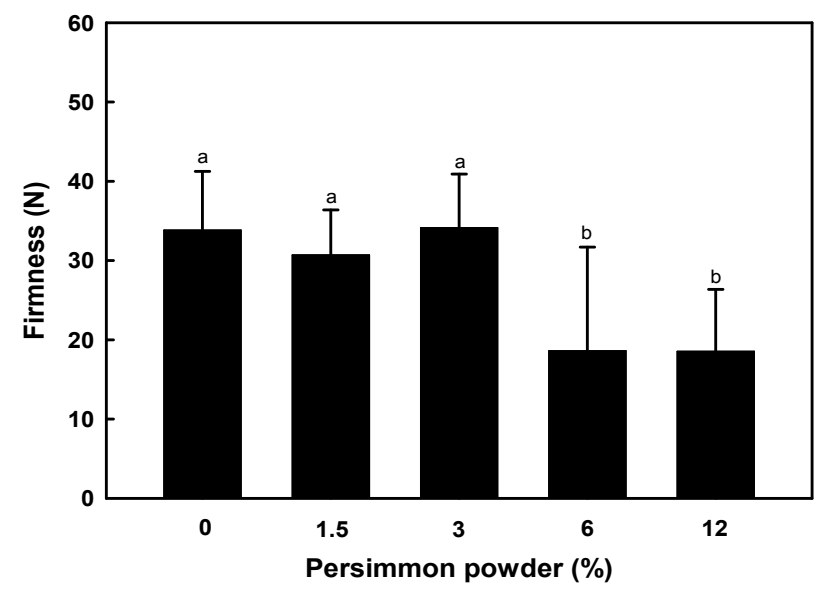

Fig. 2. Firmness of rice cookies added with different amounts of young persimmon powder.

Means $\leq \mathrm{SD}$ ( $\mathrm{n}=3$ ) with different letters above a bar are significantly different by Duncan's multiple range test $(\mathrm{p}<0.05)$.

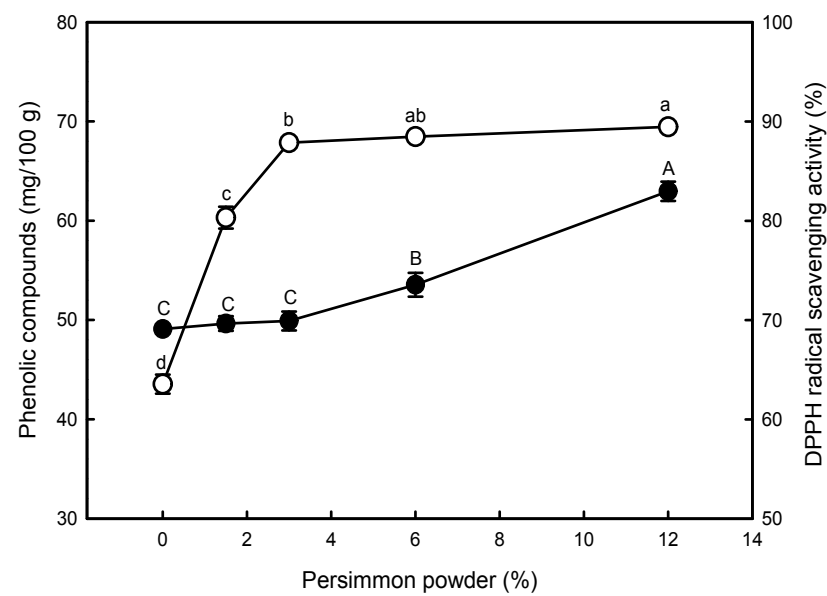

Fig. 3. Phenolic compounds (O) and DPPH radical scavenging activity $(O)$ of rice cookies added with different amounts of young persimmon powder.

Means \pm SD ( $n=3$ ) with different letters above a symbol are significantly different by Duncan's multiple range test $(\mathrm{p}<0.05)$.

함량과 DPPH 소거능을 측정한 결과는 Fig. 3 에 나타내었다. 총페놀 함량은 감 분말 $3 \%$ 이하 첨가까지는 유의적인 차이 를 보이지 않았으나 $5 \%$ 이상 첨가부터는 첨가량에 비례하 여 높아지는 것으로 확인되었다. 이는 떫은감 분말에 함유 된 페놀성 물질(8)에 기인된 것으로 여겨지고, 두부의 경우 도 감 분말의 첨가량에 비례하여 총페놀 함량이 높아지는 것으로 알려져 있다(23). 항산화능의 척도로 조사한 DPPH 유리기 소거능은 감 분말 $3 \%$ 첨가까지 큰 폭으로 증가하였 으며, 그 후부터는 감 분말의 첨가량에 비례하여 완만하게 높아짐을 보였다. 이러한 감 분말 첨가량에 따른 $\mathrm{DPPH}$ 유리기 소거능의 증가 경향이 상기한 감 분말 첨가구에서의 총페놀 함량의 변화 경향과 다소 차이를 보여 페놀성 물질 이외의 물질이 DPPH 유리기 소거능 증가에 더 크게 기여한 것으로 생각된다. 밀가루 쿠키의 항산화능도 감잎 분말 첨
가량이 증가할수록 높아지는 것으로 보고(19)된 바 있어 쌀쿠키 제조 시 어린 감 과실 분말 첨가는 제품의 항산화능 개선에 유효한 것으로 판단되었다.

이상의 모든 결과를 종합해 보면, 쌀쿠키 제조 시 어린 떫은감 분말의 첨가는 제품의 부피감소와 색을 어둡게 하고 총페놀 함량과 항산화능을 높이는 효과를 가지는 것으로 확인되었다. 이로써 쌀쿠키의 품질특성과 항산화능 등을 동시에 고려할 경우에 적합한 감 분말의 첨가량은 $3 \%$ 정도 인 것으로 판단되었다.

\section{요 약}

어린 감 과실의 활용과 쌀쿠키의 고부가가치화를 위해, 밀가루나 글루텐 무첨가 쌀쿠키의 품질특성에 어린 감 분말 의 첨가가 미치는 영향을 규명하였다. 쌀쿠키는 쌀가루 대 비 감 분말을 $0,1.5,3,6$ 및 $12 \%$ 를 각각 첨가하여 반죽을 한 다음 두께 $3 \mathrm{~mm}$ 직경 $35 \mathrm{~mm}$ 원판으로 성형한 후 $170-180^{\circ} \mathrm{C}$ 오븐에서 굽고 그의 품질특성을 조사하였다. 손실률과 퍼 짐성 지수는 감 분말첨가량에 따라 증가 후 감소하는 경향 을 보였다. 수분함량과 수분활성도는 감 분말 첨가량에 비 례하여 높아짐을 나타내었다. 색도 $\mathrm{L}^{\star}$ 값과 $\mathrm{a}^{\star}$ 값은 감 분말 첨가량의 증가와 함께 증가됨을 보였다. 총페놀 함량과 $\mathrm{DPPH}$ 유리기 소거능은 감 분말 첨가량에 따라 증가하는 경향을 보였으며 특히, $\mathrm{DPPH}$ 유리기 소거능은 첨가량 $3 \%$ 에서 큰 폭으로 증가함을 보였다. 따라서 어린 감 과실 분말 첨가가 쌀쿠키의 이화학적 품질특성에 미치는 영향이 확인 되었고, 쌀쿠키의 일반 품질특성 저하 없이 항산화능 증대 효과를 얻을 수 있는 감 분말의 첨가량은 $3 \%$ 정도인 것으로 판단되었다.

\section{감사의 글}

이 논문은 부산대학교 기본연구지원사업(2년)에 의하여 연구되었음.

\section{References}

1. Hyun YH, Koo BS, Song JE, Kim DS (2004) Food materials. Hyungseul Publishing Co, Daegu, Korea, p $152-153$

2. Kang WW, Kim GY, Park PS, Park MR, Choi SW (1996) Antioxidative properties of persimmon leaves. Foods Biotechnol, 5, 48-53

3. Song HS, Lee HK, Jang HD, Kim JI, Park OJ, Lee MS, 
Kang MH (1996) Antimutagenic effects of persimmon leaf tea extracts in sister chromatid exchanges (SCE) assay system. J Korean Soc Food Nutr, 25, 232-239

4. Park MH, Choi C, Son GM, An BJ, Bae MJ (2000) Effect of polyphenol compounds from persimmon leaves (Diospyros kaki folium) on antiallergy. J Korean Soc Food Nutr, 29, 116-119

5. Kim HJ, Kim MK (2003) Anticancer effect of persimmon leaf extracts on Korean gastric cancer cell. Korean J Nutr, $36,133-146$

6. Funayama S, Hikino H (1979) Hypotensive principles of Diospyros kaki leaves. Chem Pharm Bull, 27, 2865-2868

7. Sa YS, Kim KA, Choi HS (2003) Purification and characterization of anti-coagulant activity fraction from persimmon stem. J Korean Soc Food Sci Nutr, 32, 1323-1327

8. Lee YR, Chung HS, Moon KD (2011) Change in the polyphenol content of Cheongdonansi persimmon fruit during development. Korean J Food Preserv, 18, 13-17

9. Choi HJ, Son JH, Woo HS, An BJ, Bae MJ, Choi C (1998) Changes of composition in the species of persimmon leaves (Diospyros kaki folium) during growth. Korean J Food Sci Technol, 30, 529-534

10. Kim SK, Lim JH, Kim YC, Kim MY, Lee BW, Chung SK (2005) Chemical composition and quality of persimmon peels according to cultivars. J Korean Soc Appl Biol Chem, 48, 70-76

11. Kim JH, Park SH, Mun HG, Lee IS, Kim JK (2006) Analysis of useful components for freeze-dried persimmon flower powder by cultivar. Korean J Food Preserv, 13, 691-696

12. Jeong YJ, Lee GD, Kim KS (1998) Optimization for the fermentation condition of persimmon vinegar using response surface methodology. Korean J Food Sci Technol, 30, 1203-1208

13. Bae SM, Park KJ, Kim JM, Shin DJ, Hwang YI, Lee SC (2002) Preparation and characterization of sweet persimmon wine. J Korean Soc Agric Chem Biotechnol, 45, 66-70

14. Bae SM, Park KJ, Shin DJ, Hwang YI, Lee SC (2001) Preparation and characterization of Jochung with sweet persimmons. J Korean Soc Agric Chem Biotechnol, 44, 88-91

15. Chung JY, Kim KH, Shin DJ, Son GM (2002) Effects of sweet persimmon powder on the characteristics of bread. J Korean Soc Food Sci Nutr, 31, 738-742
16. Hong JS, Kim MA (2005) Quality characteristics of Sulgiduck by the addition of astringency persimmon paste. Korean J Food Cookery Sci, 21, 360-370

17. Kim MJ, Oh SL (1999) Effect of pre-treatment methods on the quality improvement of persimmon leaf tea. Korean J Postharvest Sci Technol, 6, 435-441

18. Nam SG, Lee BS, Park JS, Lee WY (2006) Quality characteristics of Naengmyon added with persimmon (Diospyros kaki L. folium) leaf powder. Korean J Food Preserv, 13, 337-343

19. Lim JA, Lee JH (2016) Quality characteristics and antioxidant properties of cookies supplemented with persimmon leaf powder. Korean J Food Sci Technol, 48, 159-164

20. Chung HS, Youn KS, Seong JH, Moon KD (2007) Quality properties of tea extracts prepared with persimmon flowers. Korean J Food Preserv, 14, 148-153

21. Oh SL, Cha WS, Park JH, Cho YJ, Hong JH, Lee WY (2001) Carotenoids pigment extraction from a wasted persimmon peel. Korean J Postharvest Sci Technol, 8, 456-461

22. Kim SK, Lee GD, Chung SK (2003) Monitoring on fermentation of persimmon vinegar from persimmon peel. Korean J Food Sci Technol, 35, 642-647

23. Lee YR, Chung HS, Seong JH, Moon KD (2011) Quality characteristics of tofu with added astringent persimmon powder. Korean J Food Sci Technol, 43, 329-333

24. Ahn JY, Ha TY (2010) Nutritional excellency of rice. Food Preservation and Processing Industry, 9, 60-64

25. Kim HYL, Lee IS, Kang JY, Kim GY (2002) Quality characteristics of cookies with various levels of functional rice flour. Korean J Food Sci Technol, 34, 642-646

26. Kwon YR, Jung MH, Cho JH, Song YC, Kang HW, Lee WY, Youn KS (2011) Quality characteristics of rice cookies prepared with different amylose contents. J Korean Soc Food Sci Nutr, 40, 832-838

27. Lee EJ, Jin SY (2015) Antioxidant activity and quality characteristics of rice cookies added Kalopanax pictus leaf powder. J East Asian Soc Dietary Life, 25, 672-680

28. Kim DS, Shin J, Joo N (2017) Quality characteristics of rice cookies prepared with Stevia rebaudiana leaf. J Korean Diet Assoc, 23, 14-26

29. Jeong YJ, Han YS (2015) Antioxidative activities and quality characteristics of rice cookies with added Ligularia fischeri (Ledeb.) Turcz. powder. Korean J Food Cook Sci, 31, 733-740

30. Lee JK, Jeong JH, Lim JK (2012) Effects of emulsifiers 
on physical properties of rice cookies. J Korean Soc Food Sci Nutr, 41, 1565-1570

31. Lee JK, Lim JK (2013) Effects of pregelatinized rice flour on the textural properties of gluten-free rice cookies. J Korean Soc Food Sci Nutr, 42, 1277-1282

32. American Association of Cereal Chemists (2000) Approved methods of the AACC. St Paul, MN, USA, Method 10-50D
33. Singleton VL, Rossi JA (1965) Colorimetry of total phenolics with phosphomolybdic-phosphotungstic acid regents. Am J Enol Vitic, 16, 144-158

34. Blois MS (1958) Antioxidant determinations by the use of a stable free radical. Nature, 181, 1199-1200

35. Friedman M (1996) Food browning and its prevention: an overview. J Agric Food Chem, 44, 631-653 